\title{
Screenhouse Assessment of Reaction of Fluted Pumpkin, Telfairia Occidentalis Hook F. to Root-Knot Nematode Meloidogyne Incognita
}

\author{
N. B. IZUOGU \\ Dept of crop protection, Faculty of Agriculture \\ University of Ilorin, Nigeria \\ Tel: 234-803-616-3301Ｅ-mail: nkbetsyizuogu@yahoo.com \\ E.E.A OYEDUNMADE \\ Dept of crop protection, Faculty of Agriculture \\ University of Ilorin, Nigeria \\ Tel: 234-803-356-5952 E-mail: eeaoyedunmade@yahoo.com
}

\section{J.O. BABATOLA}

Dept of crop protection, Faculty of Agriculture

University of Ilorin, Nigeria

Tel: 234-803-329-1527

\begin{abstract}
Screenhouse studies were carried out between April - June and July - September, 2004 at the vegetable research unit of National HorticulturalResearch Institute (NIHORT), Ibadan,Nigeria to investigate the reaction of five lines of Telfairia occidentalis (EN2000-4, EN2000-6, EN2000-10, EN2000-11, EN2000-13) to different population levels $(0,5000$ and 10000 eggs) of Meloidogyne incognita race 2. Seeds from five different matured pods of Telfairia lines were planted on moist sawdust medium. They were watered every two days until germination and transplanting. Experimental layout was a completely randomized design and each treatment was replicated five times. Nematode inoculation was done at one week after transplanting. The plants were watered every two days and observation of vine length, vine girth and number of leaves commenced two weeks after transplanting (WAT) on bi weekly basis and lasted till the $10^{\text {th }}$ week. From the $4^{\text {th }}$ WAT, roots were assessed for the presence of eggs every five days in view of determining the generation time in the various lines. Soil nematode population and root gall indices were determined at the end of the trial.

Results showed that there were significant differences between the Telfairia lines in the measured parameters irrespective of the inoculum levels. EN2000-4 performed significantly better than the other lines. EN2000-13 which closely followed EN2000-4 with respect to vegetative growth, recorded significantly higher galling index than all the other lines. There were significant differences between the inoculum levels. Inoculum levels were inversely proportional to growth parameters and directly proportional to gall indices in all the lines. Chlorotic patches were also observed on the leaves of plants inoculated with 10000 eggs. The uninoculated (control) plants gave significantly better vegetative growth than their inoculated counterparts. The disparities in growth and yield responses indicate that there is genetic variability among the lines.
\end{abstract}

Keywords: Inoculum, Telfairia occidentalis, Resistance, Tolerance

\section{Introduction}

Fluted pumpkin, Telfairia occidentalis Hook F. is a viny green leaf / seed vegetable. In Nigeria, this vegetable is indigenous to west tropical rain forest area of Edo to Cross River states (Long. $7^{0}-8^{0} \mathrm{E}$ and Lat. $5^{0}-6^{0} \mathrm{~N}$ ) (Akoroda, 1990). Nowadays, it has become popular among all the ethnic groups of Nigeria (Izuogu, 2009). This vegetable has enormous potentials; nutritionally, medicinally, industrially and economically. Apart from ranking as one of the three most widely eaten vegetables in homes and restaurants across Nigeria (Abiose, 1999), the fresh leaf extract serves as high value, cheap and fast remedy tonic for anaemic and convalescent persons in view of its high ferrous content which is about 700ppm (Schippers, 2000). 
Profitable production of Telfairia occidentalis has been constrained by pests and diseases such as Telfairia Mosaic Virus (TMV), some fungi and snails (Schippers, 2000). Very scanty literature exists on the susceptibility of $T$. occidentalis to the root-knot nematode, Meloidogyne incognita. M. incognita is an obligate parasite which is highly destructive to crops in nature. The infection of M. incognita results in root galling, stunted growth and low productivity in plants (Pandey and Kaira, 2003). Babatola $(1992,2000)$ reported that the root-knot nematodes and Telfairia Mosaic Virus are so far the most important pathogens of vegetables in Nigeria and indeed most horticultural crops. The growth response and susceptibility of some of the numerous Telfairia occidentalis lines to root-knot nematode, Meloidogyne incognita have been demonstrated by some workers (Nwanguma et al., 2005). This study was therefore aimed at evaluating the reaction of five lines of Telfairia occidentalis to different levels of root-knot nematode, $M$. incognita eggs with a view of making recommendations to farmers.

\section{Materials and Methods}

This investigation was conducted between April - June and July - September, 2004 at the screenhouse of vegetable research farm at National Horticultural Research Institute (NIHORT), Ibadan. Meloidogyne incognita race 2 pure culture was previously established on Celosia argentea grown in a sandy-loam top soil using the method described by Fassuliotis (1985). This culture served as continuous source of inoculum throughout the experimental trials.

Sandy-loam top soil was collected and sterilized by adopting the method of Guatam and Goswami (2002). It was parked into perforated experimental pots at the rate of $20 \mathrm{~kg}$ per pot of $25 \mathrm{~cm}$ diameter. Seeds from five mature pods, from different lines (EN2000-4, EN2000-6, EN2000-10, EN2000-11, EN2000-13) of Telfairia occidentalis obtained from NIHORT, were extracted, depulped and air-dried overnight. Each set was separately planted on moist sawdust medium in nursery trays and watered every two days until germination and transplanting. Seedlings of Telfairia were transplanted two weeks after planting in a layout of factorial experiment fitted into a completely randomized design comprising five lines with three levels of treatment. Each treatment was replicated five times.

One week after transplanting, the five sets of seedlings were separately inoculated with three population levels of 0 , 5000 and 10000 Meloidogyne incognita eggs. The uninoculated pots (0 egg population level) served as control. The nematode eggs were extracted using the method described by Hussey and Barker (1973). The plants were watered every other day. Observation on growth response data commenced on bi-weekly basis two weeks after transplanting and lasted up to the $10^{\text {th }}$ week. Parameters measured include the vine length, vine girth, number of leaves, gall indices and final nematode population. Visual observation of leaf coloration was also recorded from the $4^{\text {th }} \mathrm{WAT}\left(3^{\text {rd }}\right.$ week after inoculation).As from the $4 \mathrm{WAT}$,plants were randomly uprooted to assess the presence of eggs in each line. This was done every five days and lasted till the $6^{\text {th }}$ week. At harvest, soil nematode population was determined using the method described by Whitehead and Hemming (1965) while the roots were rated for galling by adopting the method described by Makete (2000).

All numerical data were subjected to analysis of variance. Treatment means were separated using the new Duncan's multiple range test at 5\% probability level.

\section{Result and Discussion}

It was observed that there were significant differences between Telfairia lines inoculated with different levels of Meloidogyne incognita eggs. (Tables 1-5). Vegetative growth in the uninoculated plants was significantly higher $(p \leq 0.05)$ than the inoculated ones. Vine length was significantly higher throughout the period of observation in lines EN2000-4 and EN2000-13 whereas only EN2000-4 recorded significantly higher vine girth and number of leaves at the end of the trials than the other lines while EN2000-10 had the least vine girth. There were no significant differences in vine girth between lines EN2000-11, EN2000-6 and EN2000-13. Number of leaves was significantly higher in line EN2000-4 and this was closely followed by EN2000-13. There were no significant differences in the number of leaves between EN2000-11, EN2000-10 and EN2000-6. Line EN2000-4 exhibited the overall best vegetative performance. Observation also showed that there were significant differences between inoculum levels and in most cases the highest nematode population had the most deleterious effect on plant growth.

The observed vegetative growth reduction in the fluted pumpkin was proportional to the initial nematode population. The least vegetative growth parameters were measured in plants inoculated with 10000 eggs. Except in line EN2000-4, signs of chlorotic patches were observed on plants inoculated with 10000 eggs between 8-10 weeks after transplanting. These findings are in agreement with the earlier investigations of Mathur and Varaprasad (1979) who observed reduction in leaf number and plant height of sugar beet as nematode population increased. Nwauzor Fawole (1982) studied the relationship between root-knot nematode population density and yield of yam in Nigeria using population levels of 0, 100,1000 and 10000 Meloidogyne eggs per plant. They also 
obtained negative correlation between nematode level and yield of yam. Aminu-Taiwo (2005) had similar reports on the pathogenicity of root-knot nematodes on fluted pumpkin.

Higher leaf number observed in lines EN2000-4 and EN2000-13 implies higher photosynthetic ability and assimilation of dry matter. Chlorotic patches observed at high level of inoculum in four of the lines would translate to lower photosynthetic ability of the leaves as well as reduced market value of the vegetable and reduced income for the farmer. This agrees with the earlier findings by Jain (1992), who reported that chlorosis of foliage lowered the quality of vegetable crops resulting to severe losses. Though line EN2000-13 had a high number of leaves, its infection by high level of $M$. incognita over a longer period of time would result to economic loss. The generation time (when eggs were observed) in M. incognita was shorter (22-26days) in EN2000-13 compared to EN2000-4 which occurred between 32-36 days (Table4).Shorter generation time suggests more susceptibility while longer generation time which translated to low gall index is a reflection of low root-knot nematode infection and damage as recorded in EN2000-4.This therefore accounts for its enhanced root development and ability to tap nutrient from the soil to carry out normal physiological functions. The overall varietal differences observed in the growth, yield and gall indices among the Telfairia lines in this study, irrespective of the initial nematode population could be attributed to their genetic make up which probably conferred high resistance/tolerance to EN2000-4 and tolerance to EN2000-13. This result agrees with the works of Robert et al. (1996) who reported that some ITTA cowpea varieties had strong resistance to several root-knot nematodes. They observed that IT845-2049 had slightly greater resistance which is conferred by a dominant allele at the RK locus, or by another tightly lined gene within 0.17 map units of gene RK. In addition to genetic make up causing varietal crop-nematode responses among the lines, other factors could be environmental and crop management practices.

This study has shown that the five lines of Telfairia occidentalis Hook F. investigated were susceptible to root-knot nematode at varying levels. It is therefore recommended that (i) soils be screened for the presence / level of root-knot nematode, M. incognita prior to planting of Telfairia occidentalis (ii) highly nematode infested soil be treated before embarking on such programmes in order to ensure high qualitative harvest (iii)Resistant and tolerant varieties such as EN2000-4 and EN2000-13 be multiplied and made available to farmers in order to boost $\underline{\text { Telfairia }}$ production in Nigeria.

\section{References}

Abiose, s. (1999). Assessment of the extent of use of indigenous African foods, introduced foods and imported foods in hotels and other commercial eating places in south western Nigeria. J. J. Baidu-Forson(Ed.) African's natural resources conservation, UNU / INRA

Akoroda, M. O. (1990). Ethnobotany of Telfairia occidentalis (Cucurbitaceae) among Igbos of Nigeria. Tropical Agricultural Trinidad.

Amino - Taiwo, B. R. (2005). Pathogenicity of the root-knot nematode, Meloiddogyne incognita (Kofoid and White) Chitwood (1949) on Fluted pumpkin Telfairia occidentalis Hook. F. M.Sc. Thesis, University of Ibadan, Nigeria.

Babatola, J. O. (1992). The biology of nematodes: Implications for the management of nematode pests of food crops. In B. O. Fawole, A. Egunjobi, S. O. Adesina. J. O.Babatola and A. A. Idowu(Eds. ), Biology and control of nematode pests of food crops in Africa. Info. Resource Management Ltd. pp. 95-116.

Babatola, J. O. (2000). Nematode problem of local leaf vegetables in South Western Nigeria. ISHS Acta Horticulture. African symposium on Horticultural crops, 123,6 (http:www.actahort.org).

Fassuliotis, G. (1985). The role of nematologists in the development of resistant cultivars. In J. S. Sasser and C.C. Carter(Eds.), Advanced Treatise on Meloidogyne. Vol. 1: Biology and control, pp.234.

Gautam C. and Goswami, B. K. (2002). Different combinations of neem cake and carbofuran against meloidogyne incognita on vigna radiate. International jornal of Nematology, 12, (1):106 - 110.

Hussey, R. S. and Barker, K. R. (1973). A comparison of methods of collecting inocula of Meloidogyne spp. including a new technique. Plt. Dis. Reptr, 57, 1028.

Izuogu, N. B. (2009). Pathogenicity and Control of Meloidogyne incognita (Kofoid and White) Chitwood on fluted pumpkin (Telfairia occidentalis Hook. F. Ph.D. Thesis. University of Ilorin Nigeria, pp.2.

Jain, R. R. (1992). Nematodes of vegetable crops. In nematode pests of crops CBS publishers, pp77-86.

Makete, T. (2000). Damage potentials of Meloidogyne incognita and M.javanica populations from Ethiopia and Belgium. M.Sc. Thesis. University of Ghent, Belgium, pp.46. 
Mathur, V. K. and Karaprasad, K. S. (1979). Pathogenicity and life cycle of M. incognita on sugar beet in India. Indian Journal of Nematology.

Nwanguma, E. I, Olufolaji, A.O. and Akintoye, H. A. (2005). Growth response and susceptibility of Telfairia occidentalis Hook. Lines to the Root-knot nematode, Meloidogyne incognita. Nig. Journal of Hort. Science, 10, 52-58.

Pandey, R. and kaira, A. (2003). Root-knot disease of ashwagandha Withania somnifera and its ecofriendly cost effective management. J. Mycol. Pl. Pathol., 33(2), 240-24.

Schippers, R. R. (2000). African Indigenous vegetables. An overview of the cultivated species. Chatham, U.K, NRI, CTA, DFID, pp. 214.

Whitehead, A.G. and Hemming J.R. (1965). A comparison of some quantitative methods of extracting vermiform nematodes from soil. Ann. Appl. Biol., 52,25-28.

Table 1. Effect of Pumpkin lines and Meloidogyne incognita eggs on Mean Vine

Length $(\mathrm{cm})$ of Telfairia occidentalis

\begin{tabular}{llllll}
\hline Telfairia Line & 2 WAT & 4 WAT & 6 WAT & 8WAT & 10 WAT \\
\hline EN2000-4 & $67.00 \mathrm{a}$ & $102.67 \mathrm{a}$ & $159.80 \mathrm{a}$ & $219.87 \mathrm{a}$ & $278.53 \mathrm{a}$ \\
EN2000-6 & $68.40 \mathrm{a}$ & $100.73 \mathrm{a}$ & $134.27 \mathrm{~b}$ & $166.87 \mathrm{~b}$ & $213.87 \mathrm{~b}$ \\
EN2000-10 & $60.00 \mathrm{~b}$ & $93.20 \mathrm{~b}$ & $127.13 \mathrm{~b}$ & $168.20 \mathrm{~b}$ & $203.87 \mathrm{~b}$ \\
EN2000-11 & $58.08 \mathrm{~b}$ & $95.20 \mathrm{~b}$ & $127.20 \mathrm{~b}$ & $168.07 \mathrm{~b}$ & $199.27 \mathrm{~b}$ \\
EN2000-13 & $68.33 \mathrm{a}$ & $107.80 \mathrm{a}$ & $155.27 \mathrm{a}$ & $209.73 \mathrm{a}$ & $263.07 \mathrm{a}$ \\
\hline Nematode Population & & & & & \\
\hline 0 egg (control) & $67.44 \mathrm{a}$ & $107.28 \mathrm{a}$ & $168.32 \mathrm{a}$ & $251.28 \mathrm{a}$ & $327.32 \mathrm{a}$ \\
5000 eggs & $61.60 \mathrm{~b}$ & $96.52 \mathrm{~b}$ & $134.00 \mathrm{~b}$ & $169.08 \mathrm{~b}$ & $209.96 \mathrm{~b}$ \\
10000 eggs & $64.04 \mathrm{ab}$ & $95.96 \mathrm{~b}$ & $120.00 \mathrm{c}$ & $139.28 \mathrm{c}$ & $157.88 \mathrm{c}$ \\
\hline
\end{tabular}

Table 2. Effect of Pumpkin Lines and Meloidogyne incognita eggs on Mean Vine Girth $(\mathrm{cm})$ of Telfairia occidentalis

\begin{tabular}{llllll}
\hline Telfairia Line & 2 WAT & 4 WAT & 6 WAT & 8 WAT & 10 WAT \\
\hline EN2000-4 & $1.28 \mathrm{a}$ & $1.67 \mathrm{a}$ & $1.93 \mathrm{a}$ & $2.18 \mathrm{a}$ & $2.41 \mathrm{a}$ \\
EN2000-6 & $1.25 \mathrm{a}$ & $1.51 \mathrm{~b}$ & $1.71 \mathrm{~b}$ & $1.91 \mathrm{~b}$ & $2.10 \mathrm{bc}$ \\
EN2000-10 & $1.18 \mathrm{a}$ & $1.49 \mathrm{~b}$ & $1.68 \mathrm{~b}$ & $1.88 \mathrm{~b}$ & $2.07 \mathrm{c}$ \\
EN2000-11 & $1.27 \mathrm{a}$ & $1.51 \mathrm{~b}$ & $1.71 \mathrm{~b}$ & $1.93 \mathrm{~b}$ & $2.11 \mathrm{bc}$ \\
EN2000-13 & $1.22 \mathrm{a}$ & $1.52 \mathrm{~b}$ & $1.73 \mathrm{~b}$ & $1.95 \mathrm{~b}$ & $2.17 \mathrm{~b}$ \\
\hline Nematode Population & & & & \\
\hline 0 egg (Control) & $1.25 \mathrm{a}$ & $1.54 \mathrm{a}$ & $1.86 \mathrm{a}$ & $2.19 \mathrm{a}$ & $2.51 \mathrm{a}$ \\
5000 eggs & $1.25 \mathrm{a}$ & $1.54 \mathrm{a}$ & $1.75 \mathrm{~b}$ & $1.97 \mathrm{~b}$ & $2.51 \mathrm{~b}$ \\
10000 eggs & $1.22 \mathrm{a}$ & $1.54 \mathrm{a}$ & $1.62 \mathrm{c}$ & $1.75 \mathrm{c}$ & $1.85 \mathrm{c}$
\end{tabular}

Each value is a mean of five replicates. Figures with same letter(s) in the same column are not significantly different using Duncan's Multiple range test at $\mathrm{P}=0.05$ (S.A.S 1997 Statistical Package)

WAT $=$ Weeks after transplanting

N.S $=$ Not Significant 
Table 3. Effect of different Egg Population densities of Meloidogyne incognita on Mean Number of Leaves of Telfairia occidentalis

\begin{tabular}{llllll}
\hline Telfairia Line & 2 WAT & 4 WAT & 6 WAT & 8WAT & 10 WAT \\
\hline EN2000-4 & $17.27 \mathrm{c}$ & $35.20 \mathrm{~b}$ & $51.07 \mathrm{a}$ & $68.33 \mathrm{a}$ & $97.33 \mathrm{a}$ \\
EN2000-6 & $16.87 \mathrm{c}$ & $30.80 \mathrm{c}$ & $44.87 \mathrm{c}$ & $53.67 \mathrm{c}$ & $75.07 \mathrm{c}$ \\
EN2000-10 & $27.47 \mathrm{a}$ & $39.73 \mathrm{a}$ & $46.13 \mathrm{bc}$ & $61.93 \mathrm{~b}$ & $78.73 \mathrm{a}$ \\
EN2000-11 & $24.80 \mathrm{~b}$ & $40.07 \mathrm{a}$ & $48.00 \mathrm{~d}$ & $57.20 \mathrm{~d}$ & $75.13 \mathrm{c}$ \\
EN2000-13 & $16.80 \mathrm{c}$ & $29.13 \mathrm{c}$ & $40.73 \mathrm{~d}$ & $59.53 \mathrm{bc}$ & $88.67 \mathrm{~b}$ \\
Nematode Population & & & & & \\
\hline 0 egg (Control) & $21.84 \mathrm{a}$ & $39.32 \mathrm{a}$ & $56.92 \mathrm{a}$ & $77.24 \mathrm{a}$ & $115.00 \mathrm{a}$ \\
5000 eggs & $19.24 \mathrm{~b}$ & $32.68 \mathrm{~b}$ & $42.84 \mathrm{~b}$ & $55.36 \mathrm{~b}$ & $75.60 \mathrm{~b}$ \\
10000 eggs & $20.84 \mathrm{ab}$ & $32.96 \mathrm{~b}$ & $38.72 \mathrm{c}$ & $47.80 \mathrm{c}$ & $58.36 \mathrm{c}$
\end{tabular}

Each value is a mean of five replicates. Figures with same letter(s) in the same column are not significantly different using Duncan's Multiple range test at $\mathrm{P}=0.05$ (S.A.S 1997 Statistical Package)

WAT $=$ Weeks after transplanting

Table 4. Root- knot nematode Egg Detection

\begin{tabular}{|l|l|l|l|}
\hline Line & 22-26 DAI & 27-31 DAI & 32-36 DAI \\
\hline EN2000-4 & - & - & + \\
\hline EN2000-6 & - & + & + \\
\hline EN2000-6 & - & + & + \\
\hline EN2000-10 & - & + & + \\
\hline EN2000-11 & - & + & + \\
\hline EN2000-13 & + & + & + \\
\hline
\end{tabular}

DAI $=\quad$ Days after inoculation

$+\quad=$ Eggs Present

- $\quad=$ Eggs Absent

Table 5. Effect of Egg Population Densities of M. incognita on Soil Nematode Population and Mean Gall Index of Telfairia occidentalis

\begin{tabular}{llll|lll}
\hline \multicolumn{3}{c|}{ Soil Nematode Population } & \multicolumn{3}{c}{ Root Gall Indices } \\
\hline Line & 0eggs & 5000 eggs & $\mathbf{1 0 ~ 0 0 0 ~ e g g s ~}$ & 0 eggs & $\mathbf{5 0 0 0}$ eggs & $\mathbf{1 0 ~ 0 0 0 ~ e g g s}$ \\
\hline EN2000-4 & 0 & $147.09 \mathrm{a}$ & $310.23 \mathrm{a}$ & 0 & $1.3 \mathrm{a}$ & $1.5 \mathrm{a}$ \\
EN2000-6 & 0 & $309.36 \mathrm{~d}$ & $510.73 \mathrm{c}$ & 0 & $2.2 . \mathrm{c}$ & $2.6 \mathrm{c}$ \\
EN2000-10 & 0 & $248.73 \mathrm{c}$ & $485.50 \mathrm{bc}$ & 0 & $1.9 \mathrm{~b}$ & $2.2 \mathrm{~b}$ \\
EN2000-11 & 0 & $176.67 \mathrm{~b}$ & $460.10 \mathrm{~b}$ & 0 & $1.7 \mathrm{~b}$ & $2.0 \mathrm{~b}$ \\
EN2000-13 & 0 & $530.60 \mathrm{e}$ & $870.67 \mathrm{~d}$ & 0 & $2.8 \mathrm{~d}$ & $3.4 \mathrm{~d}$ \\
\hline & & & N.S & \\
\hline
\end{tabular}

Each value is a mean of three replicates. Figures with same letter(s) in the same column are not significantly different using Duncan's Multiple range test at $\mathrm{P}=0.05$ (S.A.S 1997 Statistical Package)

WAT $=$ Weeks after transplanting

N.S $=$ Not Significant 